УДК 94:355 (477) «1917»

ДЕМ'ЯНЮК О. Й.

https://orcid.org/0000-0002-0034-5768

https://doi.org/10.33577/2313-5603.31.2019.124-139

\title{
ВТРАТА БОСЗДАТНОСТІ РОСІЙСЬКОГО ВІЙСЬКА У 1917 р. (НА ПРИКЛАДІ 11-ї АРМІї ПІВДЕННО-ЗАХІДНОГО ФРОНТУ)
}

У статті розглядаються проблеми, пов'язані з втратою боєздатності військових підрозділів російської імператорської армії, які воювали на терені відповідальності командування Південно-Західного фронту. За приклад взято російську 11-ту армію, яка впродовж 1917 р. воювала в складі Південно-Західного фронту на території Волині та Галичини. Досліджуються та аналізуються причини цього явища, насамперед, більшовицька агітація в регулярному війську, створення солдатських комітетів, випадки дезертирства, саботажу наказів командування. Тут важливо вказати, що млявий перебіг війни у 1917 р. та агітація у бойових підрозділах різних політичних сил робили свою справу - армія починала втрачати дисципліну, а відтак і боєздатність.

Ключові слова: Південно-Західний фронт, 11-та армія, Українська Центральна Рада, російське військо, більшовицька агітація.

Постановка проблеми та ї̈ актуальність. Затяжний характер, якого набула Перша світова (Велика) війна, змінив ставлення до військового протистояння не лише цивільного населення, яке було обтяжене військовими повинностями, але й військових, здебільшого iз солдатського середовища, які по кілька років не були вдома. На зміну патріотичному пориву у 1914 р. прийшло розчарування, поступове усвідомлення безперспективності ведення бойових дій у 1917 р.

Саме 1917 р. став переломним у ставленні особового складу військових підрозділів російської імператорської армії до війни, до військово-політичних обставин, тісно 3 нею пов'язаних. Східний фронт, який проходив українськими землями через територію Волині й Галичини, після низки бойових операцій у 1916 р. перетворився на лінію розмежування 3 перманентними бойовими діями, які не мали стратегічного значення як для цієї території, так і для загального стану війни.

Дем'янюк Олександр Йосипович, доктор історичних наук, професор, проректор з науково-педагогічної роботи та моніторингу якості освіти Волинського інституту післядипломної педагогічної освіти, м. Луцьк.

С Дем'янюк О.Й., 2019 
Окрім того, 1917 р. став роком революційних змін на теренах Російської імперії. Ці процеси активізували низку негативних перетворень у військових підрозділах російської армії, що, у свою чергу, призвело до зниження бойової готовності імператорського війська. Наростання більшовицької агітації у військових частинах призвело до радикалізації погляди солдатів, матросів та офіцерів, a, відтак, почастішали випадки дезертирства, саботажу наказів командування, залишення бойових позицій, мародерства тощо. Ці та інші чинники зумовили доцільність наукового опрацювання матеріалів щодо діяльності військових підрозділів російської армії у 1917 p.

Аналіз попередніх досліджень і публікаиій. Формуючи загальну картину бойових дій під час Першої світової війни на Східному фронті, вітчизняні вчені вивчали окремі військові операції, перебіг бойових дій, військово-політичні події, які відбувалися в цей час та впливали на ситуацію на фронтах. Проте детального дослідження процесів, які відбувалися в окремих військових частинах упродовж нетривалого часу нами не виявлено. Однак на увагу заслуговують праці Л. Дещинського про події на Південно-Західному фронті у 1917 р. (1999), О. Дем'янюка про військово-політичну ситуацію у військових підрозділах, які дислокувалися на Волині в 1917 р. (2010), P. Зінкевича про збройну боротьбу в арміях Південно-Західного фронту наприкінці 1917 р. (2007, 2008), А. Науменка про ситуацію в арміях Південно-Західного фронту (2009).

Мета та завдання дослідження. 3 огляду на стан наукової розробки пропонованої проблеми, розглянемо ключові причини втрати боєздатності російського імператорського війська, зокрема частин 11-ї армії Південно-Західного фронту, з'ясуємо ступінь поширення в підрозділах армії дезертирства, мародерства, росту рівня злочинності, порушень вимог військових статутів.

Виклад основного матеріалу дослідження. До складу ПівденноЗахідного фронту, про який буде йти мова в статті, у 1917 р. входили: 7-ма, 8-ма, 9-та, 11-та Осібна армії, а також короткий час (липень - вересень 1917 р.) 1-ша армія. На початок 1917 р. командувачем 11-ї армії був генерал від інфантерії Д. Баланін.

Наприкінці 1916 - на початку 1917 рр. зафіксовано поширення невдоволення серед солдатів російської армії. Війна, яка за планами російського уряду повинна була бути нетривалою та переможною, затягувалася. Солдати-селяни, відірвані від господарства та землі, починали тяготитися війною. Зменшилася мотивація до захисту 
держави, звузилося ідеологічне підгрунтя «війни до переможного кінця», зросла соціалізація і більшовизація армії. Вже на початку 1917 р. в арміях Південно-Західного фронту налічувалося 32 більшовицькі групи і 3 військові організації.

3 огляду на ситуацію, яка склалася у розташуванні ПівденноЗахідного фронту, командування доповідало в ставку Верховного головнокомандувача: «Основна маса мобілізованих перебуває під впливом більшовиків» (Акимов, 1997:90).

У період кількамісячного зимово-весняного «сидіння» серед солдатів 3'явилися агітатори i, користуючись певним затишшям на фронті, проводили пропаганду соціалістичних ідей соціальноекономічного характеру, які попадали на податливий грунт. На фоні соціальної руйнації почали розквітати правопорушення та злочинність. Почастішали випадки зловживання службовим становищем, підробки документів, спекуляції, ошуканства; різко зросла кількість крадіжок і грабунків. Із щоденника начальника 4-ї Фінляндської стрілецької дивізії (II армійський корпус 11-ї армії) генераллейтенанта В. Сєлівачова дізнаємося про падіння бойового духу навесні 1917 р. й серед офіцерів. Так, молодший офіцер, який збирався йти в розвідку, заговорив з розвідником і сказав, що «війна не закінчиться на нашу користь, але як би вона не закінчилася, а я після війни зніму мундир та виїду в Німеччину» (Селивачев, 1925:121).

Крім того, у прифронтовій зоні розпочало шириться дезертирство. Російське командування для боротьби з дезертирством змушене запровадити особливий режим у Рівному, Жмеринці, Підволочиську, Новоселиці, Проскурові, Бердичеві, Житомирі (Бернадський, 1999:15).

Доволі млявий перебіг війни на Східному фронті, який був притаманний фактично для всього 1917 р., та агітація у військах різних політичних сил робили свою справу. Армія поступово починала втрачати дисципліну, а відтак і боєздатність. 24 квітня 1917 р. командувач 11-ю армією генерал-лейтенант А. Гутор доповідав головнокомандувачу Південно-Західним фронтом генералу від кавалерії О. Брусилову: «Визнаю очевидну необхідність самої енергійної боротьби з ситуацією, яка склалася у війську, щоб не довести його до повного розпаду та повної втрати ним боєздатності» (Гутор, 1968:73). Це, у свою чергу, радикально впливало на зміни у прифронтових повітах як з російського, так і з австро-німецького боку. 
У військових підрозділах ворогуючих сторін поширювалися листівки антивоєнного та антидержавного змісту. Противники обмінювалися пропагандистськими акціями в чужих окопах. Так, німецьке командування Східного фронту поширювало в російських окопах листівки, де йшлося про те, що «російські солдати є жертвами британських підбурювачів» і висловлювалась готовність вести переговори не $з$ офіційним Петербургом, хто б там не був при владі, а 3 будь-яким російським воєначальником (Gilbert, 1994:318,319). Австрійці, за твердженням командувача 11-ю армією генерал-лейтенанта А. Гутора, «...наполегливо працюючи над розпадом нашої (російської - О. Д.) армії, не вбереглися й самі від зарази розпаду й на цей момент не можуть вповні назвати свою армію боєздатною. Принаймні, те, що спостерігається в австрійських частинах перед фронтом армії, по характеру наближається до стану нашого війська» (Гутор, 1968:73).

Під час осінньо-зимового періоду 1916 - 1917 рр. серед особового складу армій Південно-Західного фронту починає ширитися агітаційна робота російської соціал-демократичної робітничої партії. Обидві їі гілки - більшовики та меншовики - боролися за вплив на солдатське середовище. Позиція більшовиків для більшості солдатів російської армії була ближчою. Завдяки пропаганді та агітації вони збільшували соціальне підгрунтя для своїх ідей серед армій Південно-Західного фронту.

Уже до лютого 1917 р. на Південно-Західному фронті працювали окремі більшовицькі агітатори, які після Лютневої буржуазної революції в Росії почали діяти в армії відкрито, подекуди своїми вчинками загрожуючи боєздатності російського війська. Сильними позиції більшовиків були й в 11-й арміі. У телефонограмі Верховному головнокомандувачу командувач Південно-Західного фронту генерал від кавалерії О. Брусилов, характеризуючи вплив більшовиків на солдатські маси, зазначав, що «на темну масу їхній вплив поза сумнівом продовжує бути шкідливим і боротьба з ним важка» (Гончаров, 2010:208). Очевидно, що такі намагання більшовиків призводили до збільшення кількості антистатутних виступів, непокори командуванню, саботуванні команд, дезертирства, братання. Під час відвідування військовим міністром Росії А. Керенським частин 11-ї армії йому нерідко доводилося вступати в полеміку 3 солдатами. Про один такий епізод, що стався наприкінці червня 1917 р., згадував начальник штабу 11-ї армії генерал-майор Б. Геруа: 
«Міністр вийшов 3 автомобіля-трибуни та запропонував солдатам розповісти йому про свої потреби. Стрій, і без того мало на нього схожий, перетворився в звичайний натовп. Керенського тісно обступила купка солдатів. Один із них, сміливий та розв'язний, миттєво розпочав викладати свої «тріади». Вони зводилися до того, що «ми свою справу зробили» і що необхідно частини на передовій змінити й відвести в тил» (Геруа, 1970:195).

Гасла, навіювані більшовицькими агітаторами, опановували солдатські маси та перекочовували у свідомість місцевого населення. Простий люд «легко й довірливо йшов за комуністичними гаслами, які він добре розумів, а гасла національні були йому аж надто мало знані» (Огієнко, 1968:5).

Альтернативою до поширення більшовицької пропаганди в російському війську та створення рад солдатських депутатів став український рух. Уже в березні 1917 р. в армії почали організовуватися українські ротні громади. В них групувалися солдати-земляки 3 різних повітів України. 3'явилися українські військові ради та комітети. Їх діяльність була скерована на піднесення національної самосвідомості солдатів-українців. У підрозділах Південно-Західного фронту створювалися різноманітні військові гуртки, клуби, ради та інші організації. Так, уже в квітні 1917 р. вони були організовані у XXIV армійському корпусі 11-ї армії, в 155-й Піхотній дивізії 11-ї армії, в гарнізонах Тернополя, Рівного, Житомира (Нова Рада, 1917).

Комісар 11-ї армії А. Чекотило, повідомляючи військового міністра Тимчасового уряду Росії генерал-майора А. Верховського про складну морально-етичну ситуацію в армії, зазначав, що він звертався за допомогою до Української Центральної Ради, позаяк «4-та дивізія входить до складу українізованого VI корпусу, чому голос Центральної ради буде особливо вагомим» (Исторический архив, 1957:49).

Однак навесні 1917 р. цей рух ще не набув масовості та не міг виступати структурованою ідеологічною одиницею. Українські політичні партії відносилися до українського військового руху, як, зрештою, і до українських військових формувань з пересторогою та нерозумінням їх важливості для поточного історико-політичного моменту.

Поряд із тим слід зазначити, що серед солдатського середовища військових частин більшовицька пропаганда та іiі соціальні гасла знаходили щораз більше прихильників. Уже від весни 1917 р. на 
фронті 11-ї армії поширюється братання 3 солдатами ворожих армій. 13 квітня 1917 р. командувач 11-ю армією генерал-лейтенант А. Гутор рекомендував командирам корпусів низку заходів задля припинення братання на фронті: «Останнім часом повсюдно помітне посилення братання з ворогом й мовчазна, ніби за взаємною згодою, домовленість не стріляти. В чергове наполягаю на використанні у викоріненні цього зла всіх можливих заходів, причому кращим засобом вважаю періодичні обстріли легкої артилерії» (Гапоненко, 1958:497). А вже 24 квітня, доповідаючи головнокомандувачу Південно-Західним фронтом генералу від кавалерії О. Брусилову, генерал-лейтенант А. Гутор змушений був констатувати, що «спроби артилерії припинити братання зустрічаються піхотою з величезною злобою, аж до загрози жорсткої розправи з батареями, які ведуть обстріл» (Гутор, 1968:67).

Єфрейтор команди розвідників 35-ї піхотної дивізії 11-ї армії Я. Кальницький згадував, що в травні 1917 р. «після братання в наших солдат з'являлися шоколад, змішана 3 цукром австрійська кава, ром, галети, інколи - жовті важкі черевики або сірі обмотки. Значно рідше з'являлися фотокартки, де було зображено російських та австрійських солдатів разом. В австрійських шанцях після братання насолоджувалися російським житнім хлібом, міцним цукром та примірювали складні папахи. Начальство багато сварилося через братання, і дійшло до того, що було виведено частини 3 перших ліній, а нас, розвідників, змусили і вдень нести охорону укріплень» (Кальницкий, 1964:28).

У повідомленні про настрої в солдатському середовищі 11-ї та інших армій Південно-Західного фронту восени 1917 р. зазначалося, що «значними групами більшовицька течія шириться, загалом настрій тривожно-вичікувальний, наповнений невизначеністю й непослідовністю. Склалося ідейне визнання більшовизму і, як наслідок, його застосування - братання» (РГВИА, ф. 2003, on. 4, д. 27, л. 267). Голова армійського комітету 11-ї армії прапорщик Н. Криленко в брошурі «Чому побігла російська революційна армія» констатував: «I відмова від наступу, і братання були значними показниками революційної енергії та революційної готовності народних мас до боротьби з війною, які необхідно було використати й скерувати» (Крыленко, 1917:22). Проти братання виступали й російські періодичні видання, які «на чолі 3 «Русским словом» виступили проти братання, називаючи його ганьбою та зрадою» (Кальнищкий, 1964:29). 
Поступово зміна суспільно-політичної ситуації всередині воюючих сторін та перенесення внутрішньодержавних настроїв на передову призвели до змін у бойових підрозділах. Ці зміни не завжди носили демократичний характер, деколи підриваючи боєздатність військових підрозділів та перешкоджаючи виконанню тактичних завдань. Про стан справ 11-ї армії повідомлялося: «Ще до прийняття закону про виборність командного складу, деякі частини започаткували в себе це право раніше його офіційної санкції. Так, комітет летючого пункту 3-ї гвардійської дивізії, відсторонив начальника i заволодів усім майном; комітет санітарного потяга змістив старшого лікаря, завідуючого господарством і сестер милосердя і вибрав нових осіб (11-та армія)» (Гончаров, 2010:360).

На початку грудня 1917 р. $з$ частин 11-ї армії надходили ще сумніші новини. Виконувач обов'язків начальника військовополітичного відділу уповноваженого начальника штаба верховного головнокомандувача А. Сорочан доповідав, що «солдатами 22-го стрілецького полку вбито начдива 6-ї Сибірської дивізії Петрова та арештовано начальника штабу дивізії Колецького» (Гончаров, 2010:470).

Втручання в командування військовими частинами в бойових умовах та дискредитація генералітету перед особовим складом розкладали дисципліну та ширили анархію у військах: «Трагізм вищого командного складу полягає ще й в тому, що замість того, аби віддані обов'язку частини виступали проти ворога, він повинен їх скеровувати для втихомирювання охоплених заколотом полків $\mathrm{i}$ цілих дивізій в тилу й для припинення мародерства та грабунку» (Красный архив, 1933:97).

Командувач 11-ї армії генерал-лейтенант А. Гутор доповідав головнокомандувачу Південно-Західного фронту генералу від кавалерії А. Брусилову: «Дисципліна у війську впала до межі. Нової, свідомої дисципліни ще не створено. Це служить приводом до виникнення різноманітних інцидентів. Спостерігалися випадки відмови частин виходити на заняття, на роботи; було два випадки відмови від виступу на позиції» (Гутор, 1968:68).

У липні 1917 р. генерал від інфантерії П. Балуєв, прийнявши командування над 11-ю армією, змушений був констатувати: «Ознайомившись 3 настроєм військ, я вжахнувся від цієї ганьби і загибелі, які загрожують Росії та революції. Багато частин перетворилося на ненавчені, недисципліновані озброєні ватаги, які не 
тільки протидіють ворогу, але почасти розбігаються від одного лише натяку на його присутність» (Красный архив, 1933:98).

Почастішали відмови солдатів регулярної російської армії виконувати військову присягу, вести бойові дії, зміцнювати оборонні рубежі. 12 липня 1917 р. солдати 8-го Туркестанського стрілецького полку відмовилися брати участь у наступі на Ковель. Солдати 501-го стрілецького полку, який розташовувався в Луцьку, відмовилися виступати на бойові позиції.

На початку липня 1917 р. солдати лейб-гвардійського Гренадерського полку відмовилися виступати на позиції. Полковник Громико повідомляв, що «довелося застосувати збройну силу й змусити полк задати організаторів, які в числі декількох офіцерів та близько 130 солдатів арештовані й передані суду. Полк не розформувався, але наступати відмовився й був відведений в тил для оздоровлення» (Красный архив, 1933:94).

На прифронтових територіях почали діяльність ради солдатських депутатів та солдатські комітети. Петроградська рада робітничих і солдатських депутатів наказом № 1 закріпила існування уже діючих комітетів і зобов'язала створити там, де їх ще не було. Зазначеним наказом солдатські комітети наділялися повною політичною владою на місцях та зосереджували у своїх руках всі основні функції командування. Відмінялося титулування офіцерів, солдати зрівнювалися в правах 3 усіма громадянами країни (Гапоненко, 1957:190). Повідомляючи про ситуацію в частинах 11-ї армії, характеризується деструктивна роль комітетів різних рівнів. Зокрема, комітет частин штабу 11-ї армії прийняв рішення «реквізувати особистих офіцерських коней, обшукувати офіцерів, що від'їджжають з частин і відбирати в них зброю, перевести офіцерів на гуртожиток» (Гончаров, 2010:361).

Щоб якимось чином контролювати створення та діяльність солдатських комітетів, ставка «Тимчасовим положенням по організації чинів діючої армії і флоту» визначила місцем створення комітетів роти, полки, дивізії, корпуси, армії, штаби фронтів. До літа 1917 р. на Південно-Західному фронті до складу комітетів різних рівнів входило більше 75 тис. солдатів.

На комітети покладалися дисциплінарні, господарські та освітні функції, зв'язки 3 політичним партіями, агітаційно-ораторська робота у військах, розповсюдження літератури (Дещинський, 1999:14). Так, 30 червня 1917 р. армійський комітет 11-ї армії у присутності 
представників корпусних, дивізійних та фронтового комітетів, обговоривши ситуацію в армії, констатував, що «теперішня ситуація в тилу і на фронті, яскраво проявилася після останнього наступу, далі продовжуватися не може та загрожує повним провалом усіх завоювань революції» (Гончаров, 2010:233).

Командарм 11-ї армії генерал-лейтенант А. Гутор заявляв, що «майже всі резолюції військових частин і заяви делегатів частин в армійському комітеті сходяться в одному - відчувається надзвичайна перевтома війною, тотальне бажання якнайшвидшого укладення миру, причому самі делегати заявляють, що вони не виражають того настрою, який в цьому відношенні фактично існує в їхніх виборців» (Гутор, 1968:67).

Окрім комітетів, іншими виборними колегіальними організаціями у військах Південно-Західного фронту були: військові секції Рад робітничих і солдатських депутатів, військові солдатські організації та організації змішаного типу (офіцерсько-солдатські, солдатськоробітничі) (Зінкевич, 1992:19).

15 квітня 1917 р. в Кременці зібралися делегати 11-ї армії для обрання армійського комітету. Його головою було обрано більшовика прапорщика М. Криленка, який відразу почав піднімати питання припинення війни, зменшення ролі офіцерів, саботування рішення Тимчасового уряду та Української Центральної Ради. Згодом головою армійського комітету 11-ї армії став солдат Піпік, представник партії меншовиків. Комітет поділявся на фракцію більшовиків та блок фракцій соціалістів-революціонерів, меншовиківоборонців, меншовиків-інтернаціоналістів і безпартійних. Про силу більшовицьких позицій в 11-й армії свідчить факт обрання на Всеросійський з'їзд рад робітничих і солдатських депутатів трьох більшовиків та п'ятьох представників блоку інших партій (Дем'янюк, 2010:81).

На фоні занепаду бойового духу в частинах російського війська почастішали селянсько-солдатські грабунки та знищення поміщицького майна, яке зводилося до витіснення землевласників та захоплення чи поділу їх земель між селянами. Випадки вигнання 3 садиб місцевих поміщиків, а подекуди і їх фізичне знищення стали доволі поширеною практикою у прифронтовій смузі восени 1917 p.

29 листопада 1917 р. жителі с. Ільковець Кременецького повіту разом з солдатами Казанського полку VI армійського корпусу 11-ї армії пограбували, понищили майно та частково зруйнували економію Острозького повітового лікаря Прушинського (ДАВО, $\phi .49$, 
on. 1, сnр. 107, арк. 6). У селах Дмитрівка, Воронівці, Козачки Святенької волості Кременецького повіту за сприяння розквартированого в цих селах вищезгадуваного 64-го Казанського полку розгромили поміщицькі маєтки (ДАТО, ф. 241, on. 1, спр. 2, арк. 68).

27 вересня 1917 р. в м. Острог, де дислокувалися управління XXXIII запасної бригади та 266-й запасний полк, розпочався погром, що супроводжувався пожежею. Погром, що був розпочатий солдатами маршових рот Сибірського запасного полку, не вдалося зупинити власними силами. Під вечір, коли в місто увійшло чотири ескадрони улан 3 двома кулеметами, грабунки припинилися, «однак тисячі солдат 3 награбованим майном розсіялися навколишньою місцевістю. Декілька сотень таких зібралося на станції Кривин і навіть вимагали потяг» (Гончаров, 2010:380, 381).

Подекуди до грабунків та погромів солдатів провокували самі селяни. Вони, грабуючи панські маєтки, нерідко заохочували солдатів військових частин, що дислокувалися поруч, до захоплення хліба, худоби, коштовностей та іншого майна поміщиків. Вони ж показували солдатам, де знаходиться майно місцевих панів, а потім його за безцінь купували у цих самих солдатів.

Окремі військовослужбовці свідомо йшли на грабунки і погроми, вважаючи, що таким чином вони повертають собі ту частину матеріальних благ, якої вони недоотримали з вини влади. 3 іншого боку, солдатсько-селянські погроми влаштовувалися під впливом більшовицької агітації, в ім'я встановлення соціальної справедливості.

Протягом листопада 1917 р. військово-революційні комітети (ВРК) створювалися в більшості підрозділів 11-ї армії, в гарнізонах і населених пунктів повітового-волосного рівнів. 3'явилися вони в Луцьку, Ізяславі, Дубні, Староконстянтинові, Новограді-Волинську, Рівному, Коростені, Олевську та в інших населених пунктах.

Так, 2 листопада ВРК був обраний в V армійському корпусі 11-ї армії. 9 листопада почав працювати ВРК V Сибірського корпусу 11-ї армії. На зборах представників корпусів 11-ї армії, які відбулися 10 листопада в Староконстянтинові, було прийнято рішення про утворення ревкому 11-ї армії, до якого перейшла реальна влада в армії (Дещинський, 1977:120). Військово-революційні комітети також створено в XXII армійському корпусі та 50-й Сибірській піхотній дивізії 11-ї армії.

У листопаді 1918 р. з ініціативи ревкому 11-ї армії було розпочато переговори $з$ німецьким командуванням тих військ, які базувалися по той бік від лінії фронту. Спочатку обумовлено про 
припинення воєнних дій в коридорі по лінії Берестечко - Волочиськ. 24 листопада 1917 р. командування Південно-Західного фронту досягло домовленості про припинення бойових дій на всьому фронті від Пінська до Могилева-Подільського (Дещиинський, 1977:121).

Іншою ініціативою ревкомів стали перевибори командного складу всіх частин російської армії. Щодо військових підрозділів, які перебували в той час на території Волинської губернії, то, незважаючи на протести головнокомандувача Південно-Західного фронту, вони пройшли в період з 12 листопада по 16 грудня 1917 р.

За визначеною декретом Ради Народних Комісарів процедурою командири (включно 3 полковим) обиралися загальним голосуванням відповідних частин: відділень, взводів, рот, команд, ескадронів, батарей, дивізіонів, полків. Командири вище полкового обиралися з'їдами або нарадами при відповідних комітетах. У ході виборів командармом 11-ї армії став капітан Є. Бабін (Кичий, 1986:71).

До кінця 1917 р. ситуація в бойових підрозділах армії лише ускладнювалася. III з'їзд 11-ї армії, який відбувся в Кременці 3-5 грудня, це підтвердив. Під час його роботи дискусійними були політичні погляди більшовицької та есерівської партій. Так само прийнято рішення про демократизацію армії, запровадження виборності начальників, командирів та комісарів.

Висновки. Процес розпаду російського імператорського війська й, зокрема, частин 11-ї армії відображений у зведених відомостях про ситуацію в армії: «Головними мотивами, що визначають настрій солдатських мас, залишаються нестримне бажання миру, стихійне устремління в тил, бажання прийти до будь-якого розв’язку. Окрім цього, недостатньо амуніції та продовольства, відсутні будь-які заняття, через непотрібність та марнотратність їх, на думку солдат, напередодні миру, негативно впливають на настрій і приводять до розчарування» (Гончаров, 2010:358). Таким чином, опрацьовані документи періоду Першої світової війни дозволяють стверджувати, що впродовж 1917 р. російська імператорська армія поступово занепадала морально, технічно, духовно, професійно, падав бойовий дух. На прикладі 11-ї армії спостерігаємо, що для цього часу характерними рисами армійського життя були: втрата боєздатності, поширення анархії, дезертирства, кримінальних злочинів, відмова витупати на бойові позиції, братання. Усе це відбувалося на фоні зростання більшовицької агітації у війську, створенні в армії комітетів різних рівнів. 


\section{Використані посилання}

Gilbert M. 1994. The First World War. London, p. 544.

Акимов Ф. И. 1997. Большевики Украины в борьбе за солдатские массы Юго-Западного фронта. Военно-исторический журнал. № 2, c. 84-90.

Бернадський Б. В. 1999. Волинь у роки Першої світової війни: автореф. дис. на здобуття наук. ступеня канд. іст. наук: спеи. 07.00.01 «Історія України». Львів, с. 20.

Большевизаџия фронта в предъиюльские дни 1917 г. Красный архив. 1933. Т. 3, с. 97-98.

Галин В.В. 2004. Война и революиія. М.: Алгоритм, с. 592.

Гапоненко Л. С. ред. 1957. Революиионное движение в России после свержения самодержавия. Документы и материаль. М.: Изд-во АН СССР, с. 486.

Гапоненко Л. С. ред. 1958. Револючионное движение в России в апреле 1917 г. Апрельский кризис: документы и материаль. М.: Изд-во АН СССР, с. 936.

Геруа, Б. В. 1970. Воспоминания о моей жизни: в 2-х т. Париж: Танаис. Т. 2, с. 244.

Гончаров В. Л. 2010. 1917. Разложение армии. М.: Вече, с. 496.

Дем'янюк О. Й. 2010. Військово-політична ситуація на Волині восени 1917 р. Вісник Національного університету «Львівська політехніка», Держава та армія, № 670, с. 80-88.

Державний архів Волинської області (ДАВО), ф. 49, оп. 1, спр. 107.

Державний архів Тернопільської області (ДАТО), ф. 241, оп. 1, спр. 2.

Дещинський Л. Є. 1977. Великий Жовтень на Волині. Львів: Вища школа, с.183.

Дещинський Л. Є. 1999. Із історії боротьби УНР проти більшовицької агресії (грудень 1917 - січень 1918 рр.): уроки і сучасність. Вісник державного університету «Львівська політехніка», Держава та армія, № 377, с. 3-10.

Зінкевич Л. В. 1992. Політичне становище у військах ПівденноЗахідного фронту після Лютневої революції (лютий-травень 1917 р.). Вісник державного університету «Львівська політехніка», Держава та армія, № 268, с. 18-23. 
Зінкевич Р. Д. 2007. Процес українізації армії та тилових гарнізонів Південно-Західного та Румунського фронтів у березнілистопаді 1917 р. Вісник Національного університету «Львівська політехніка», Держава та армія, № 584, с. 64-70.

Зінкевич Р. Д. 2008. Політична конфронтація та збройна боротьба в арміях Південно-Західного та Румунського фронтів після приходу більшовиків до влади (кінець 1917 - початок 1919 рр.). Вісник Національного університету «Львівська політехніка», Держава та армія, № 634, с. 36-42.

Из дневника ген. В. И. Селивачева. Красный архив. 1925. Т. 2, c. $118-124$.

Из рапорта командующего 11-й армией генерал-лейтенанта А.Е. Гутора главнокомандующему армиями Юго-Западного фронта генералу Брусилову от 24 апреля 1917 года. В: Револючионное движение в русской армии, 27 февраля - 24 октября 1917 года: сборник документов. 1968. М.: Наука, с. 71-73.

Кальницкий Я. И. 1964. От Февраля к Октябрю: воспоминания фронтовика. Харьков: Государственное издательство Украины, c. 156.

Кичий И. В. 1986. Борьба за власть Советов на Правобережной Украине. Львов: Вища школа, с. 152.

Крыленко Н. В. 1917. Почему побежала русская революиионная армия. Пг.: б. и., с. 32.

Науменко А. 2009. До історії бойових дій на Волині під час Першої світової війни. Минуле і сучасне Волині та Полісся. Науковий збірник: Сторінки воєнної історії краю, Вип. 30: Мат-ли XXX Всеукр. наук.-практ. істор.-краєзн. конф. Луцьк: МП «Пульс», c. 160-164.

Нова Рада. 1917. 18, 30 квітень 1917.

О положении армии накануне Октября: (донесения комиссаров Временного правительства и командиров воинских частей действующей армии). Исторический архив. 1957, № 6, с. 48-49.

Огієнко I. 1968. Рятування Украӥни. На тяжкій службі своєму народові. Вінніпег: Вид. Товариства «Волинь», с. 96.

Российский государственный военно-исторический архив, Москва, ф. 2003, оп. 4, д. 27. 


\section{References}

Gilbert M. 1994. The First World War. London, p. 544 (eng).

Akimov F. I. 1997. Bolsheviks of Ukraine in the struggle for the soldiers' masses of the South-Western Front. Military history magazine. № 2, p. 84-90 (rus).

Bernadsky B.V. 1999. Volyn during the First World War: the author's abstract of dissertation work for the degree of historical sciences candidate: specialty. 07.00.01 «History of Ukraine». Lviv, p. 20 (ukr).

Bolshevization of the front in the pre-July days of 1917. Red Archive. 1933. T. 3, p. $97-98$ (rus).

Galin V.V. 2004. War and Revolution. M.: Algoritm, p.592 (rus).

Gaponenko L.S. ed. 1957. The revolutionary movement in Russia after the overthrow of the autocracy. Documents and materials. M.: Publishing House of the Academy of Sciences of the USSR, p. 486 (rus).

Gaponenko L.S. ed. 1958. Revolutionary movement in Russia in April 1917. April crisis: documents and materials. M.: Publishing House of the Academy of Sciences of the USSR, p. 936 (rus).

Gerua B.V. 1970. Memories of my life: in 2 volumes. Paris: Tanais. V. 2, p. 244 (rus).

Goncharov V.L. 2010. 1917. Decomposition of the army. M.: Veche, p. 496 (rus).

Demyanyuk O. Y. 2010. Military-political situation in Volyn in autumn 1917. Bulletin of the National University "Lviv Polytechnic", State and Army, No. 670, pp. 80-88 (ukr).

State Archive of Volyn Region (SAVR), f. 49, op. 1, sp. 107 (ukr).

State Archive of Ternopil Region (SATR), f. 241 op. 1, sp. 2 (ukr).

Deshchinsky L.E. 1977. Great October in Volyn. Lviv: Higher school, p.183 (ukr).

Deshchinsky L.E. 1999. From the history of the UNR struggle against the Bolshevik aggression (December 1917-January 1918): lessons and modern times. Bulletin of the State University "Lviv Polytechnic", State and Army, No. 377, p. 3-10 (ukr).

Zinkevich L.V. 1992. Political situation in the troops of the Southwest Front after the February Revolution (February-May 1917). Bulletin of the State University "Lviv Polytechnic", State and Army, № 268, p. 18-23 (ukr). 
Zinkevich R.D. 2007. The process of Ukrainianization of the army and the rear garrisons of the Southwestern and Romanian fronts in March-November 1917. Bulletin of the National University "Lviv Polytechnic", State and Army, No. 584, p. 64-70 (ukr).

Zinkevich R.D. 2008. Political confrontation and armed struggle in the armies of the Southwestern and Romanian fronts after the Bolsheviks came to power (end of 1917 - early 1919). Bulletin of the National University "Lviv Polytechnic", State and Army, No. 634, p. 36-42 (ukr).

From the diary of the gen. V.I. Selivachev. Red archive. 1925. T. 2, p. 118-124 (rus).

From the report of the 11th Army commander Lieutenant-General A.E. Gutor to the commander-in-chief of the South-Western Frontr Amies General Brusilov, dated 24 April 1917. In: The revolutionary movement in the Russian army, 27 February - 24 October 1917: a documents collection. 1968. M.: Science, p. 71-73 (rus).

Kalnitskiy Ya. I. 1964. From February to October: memories of a front-line soldier. Kharkiv: State Publishing House of Ukraine, p. 156 (rus).

Kichiy I.V. 1986. The Struggle for the Power of the Soviets in Right-Bank Ukraine. Lviv: High school, p. 152 (rus).

Krylenko N.V. 1917. Why did Russian Revolutionary Army run? PG: b.i., p. 32 (rus).

Naumenko A. 2009. The history of fighting in Volhynia during the First World War. Past and present of Volyn and Polissya. Scientific Collection: Pages of the Military History of the Region, Issue 30: Material of XXX Allukr. sci. pract. historic province. conf. Lutsk: MP "Pulse", p. 160-164 (ukr).

New Council. 1917, 18, 30 April 1917 (ukr).

On the situation of the army on the eve of October: (reports of the commissar of the Provisional Government and the commanders of military units of the active army). Historical archive. 1957, No. 6, p. 48-49 (rus).

Ogienko I. 1968. Rescue of Ukraine. On a hard service to our people. Winnipeg: View. Volyn Society, p. 96 (ukr).

Russian State Military-Historical Archive, Moscow, f. 2003, op. 4, d. 27 (rus). 


\section{Demianiuk O.}

\section{LOSS OF COMBAT CAPABILITY OF THE RUSSIAN ARMY IN 1917 (VIA EXAMPLE OF THE 11th ARMY OF THE SOUTHERN-WESTERN FRONT)}

Forming a general picture of the combat actions during the World War First (the Great War) on the Eastern Front, domestic scientists studied separate military operations, the course of hostilities, militarypolitical events that took place at that time and influenced the situation on the fronts.

Instead of this, the article deals with the problems associated with the loss of combat capability of those military units of the Russian army which were fighting in the South-Western Front (via example of the Russian 11th army).

The protracted nature of the World War First changed the attitude to the military confrontation not only of the civilian population, which was burdened with military duties, but also of the military officers (mostly of the soldiers). In 1914, instead of a patriotic enthusiasm, disappointment and gradual awareness of the worthlessness of 1917's combatting came.

The revolutionary processes of 1917 intensified a number of negative changes in the military units of the Russian army, what, in its turn, led to a decrease in the combat readiness of the imperial troops. The rise of Bolshevik agitation in military units led to the radicalization of the views of soldiers, sailors and officers, and, as a result of this, cases of desertion, sabotage of command orders, abandonment of martial law, looting and similar actions became more frequent. These and other factors led to the necessity of scientific research on the materials related to the activities of the military units of the Russian army in 1917.

We note that the sluggish course of the war in 1917 and agitation in the combat units of various political forces did their job - the army began to lose discipline and, hence, its combat capability. The revolutionary mood captured by the army, including by the 11th army, led to the collapse of the Eastern Front and further conclusion of the truce.

Keywords: Southern-Eastern front, 11th army, Ukrainian Central Council, Russian troops, Bolshevik's agitation. 